\title{
Partial Purification of Glycerate Kinase from Flavobacterium sp.
}

\author{
By ANDREW WILLETTS \\ Department of Biological Sciences, University of Exeter, Exeter EX4 4QG
}

(Received 6 March 1978)

\section{INTRODUCTION}

A Flavobacterium sp. (NCIB 11171) grown on ethylene glycol oxidized the diol to glyoxylate which was further metabolized to pyruvate by the glycerate pathway (Child \& Willetts, 1978). However, it was not established whether the reaction product of glycerate kinase in ethylene glycol-grown NCIB 11171 was 3-phosphoglycerate, as in glycerate-grown Escherichia coli operating a restricted Embden-Meyerhof-Parnas pathway (Doughty et al., 1966), or 2-phosphoglycerate, as in methanol-grown Hyphomicrobium x (Harder et al., 1973; Hill \& Attwood, 1974, 1976a), methanol-grown Pseudomonas AM1 (Hill \& Attwood, 1974, 1976a) and methylamine-grown Pseudomonas MA (Newaz \& Hersh, 1975) operating the serine pathway.

This communication describes the partial purification of glycerate kinase from ethylene glycol-grown NCIB 11171 and demonstrates indirectly that the product of the reaction is 2-phosphoglycerate.

\section{METHODS}

Micro-organism maintenance and culture. The maintenance and growth of NCIB 11171 in ethylene glycol minimal medium was as previously described (Child \& Willetts, 1978).

Preparation of cell extracts. Bacteria were suspended in $0 \cdot 1 \mathrm{M}$-potassium phosphate buffer, $\mathrm{pH} 7 \cdot 0$, and disrupted ultrasonically; the supernatant after centrifugation $\left(0^{\circ} \mathrm{C}, 10000 \mathrm{~g}, 15 \mathrm{~min}\right)$ was used as the cell extract (Child \& Willetts, 1978).

Enzyme assays. Glycerate kinase (EC 2.7.1.31), phosphopyruvate hydratase (EC 4.2.1.11), phosphoglycerate mutase (EC 2.7.5.3) and the conversion of glycerate to phosphoenolpyruvate were assayed as described by Harder et al. (1973). 3-Phosphoglycerate kinase (EC 2.7.2.3) was assayed by the method of Roustan et al. (1973).

Protein determination. Protein was assayed by a Folin-Ciocalteu method (Lowry et al., 1951) using bovine serum albumin as a standard.

Partial purification. All procedures were carried out at $0{ }^{\circ} \mathrm{C}$ unless otherwise stated.

Step 1. Ammonium sulphate fractionation. Cell extract from ethylene glycol-grown cells was adjusted to $30 \%$ saturation with ammonium sulphate, allowed to stand for $30 \mathrm{~min}$ and the precipitated protein was removed by centrifugation $\left(0{ }^{\circ} \mathrm{C}, 15000 \mathrm{~g}, 15 \mathrm{~min}\right)$. The supernatant was adjusted to $50 \%$ saturation with ammonium sulphate, allowed to stand for $40 \mathrm{~min}$ and then centrifuged as above. The resultant pellet of precipitated protein was washed twice in $0 \cdot 1 \mathrm{M}$-potassium phosphate buffer, $\mathrm{pH} 7 \cdot 0$, and resuspended in the minimum volume of buffer.

Step 2. Bio-Gel P300 gel filtration. The $50 \%$ ammonium sulphate precipitate in buffer $(3.5 \mathrm{ml}$, protein content $\left.10.42 \mathrm{mg} \mathrm{ml}^{-1}\right)$ was applied to a Bio-Gel P300 column $(35 \times 2.5 \mathrm{~cm})$ and eluted with $0.1 \mathrm{M}$-potassium phosphate buffer, $\mathrm{pH} 7 \cdot 0$, by upward-flow gel filtration. The flow rate was $0 \cdot 15 \mathrm{ml} \mathrm{min}{ }^{-1}$. Fractions $(4 \cdot 7 \mathrm{ml})$ were collected, monitored at $253.7 \mathrm{~nm}$ with an LKB Uvicord I UV absorptiometer and assayed for glycerate kinase, phosphoglycerate mutase and 3-phosphoglycerate kinase activities. Specific activity measurements of the peak fractions (Fig. 2) showed approximately 100-fold purification of glycerate kinase, 125-fold purification of phosphoglycerate mutase and 160-fold purification of 3-phosphoglycerate kinase relative to crude extract. Active fractions were stored at $-20^{\circ} \mathrm{C}$ if not used immediately.

Indirect determination of reaction product of partially purified glycerate kinase. The NADH-dependent reduction of pyruvate resulting ultimately from the phosphorylation of glycerate (Fig. 1) was assayed spectrophotometrically at $340 \mathrm{~nm}$. Partially purified glycerate kinase $(2.0 \mathrm{ml}, 4 \mathrm{mg}$ protein), free from phosphoglycerate mutase activity, was incubated for $30 \mathrm{~min}$ at $25^{\circ} \mathrm{C}$ in a reaction mixture (final vol. $4.0 \mathrm{ml}$ ) con- 


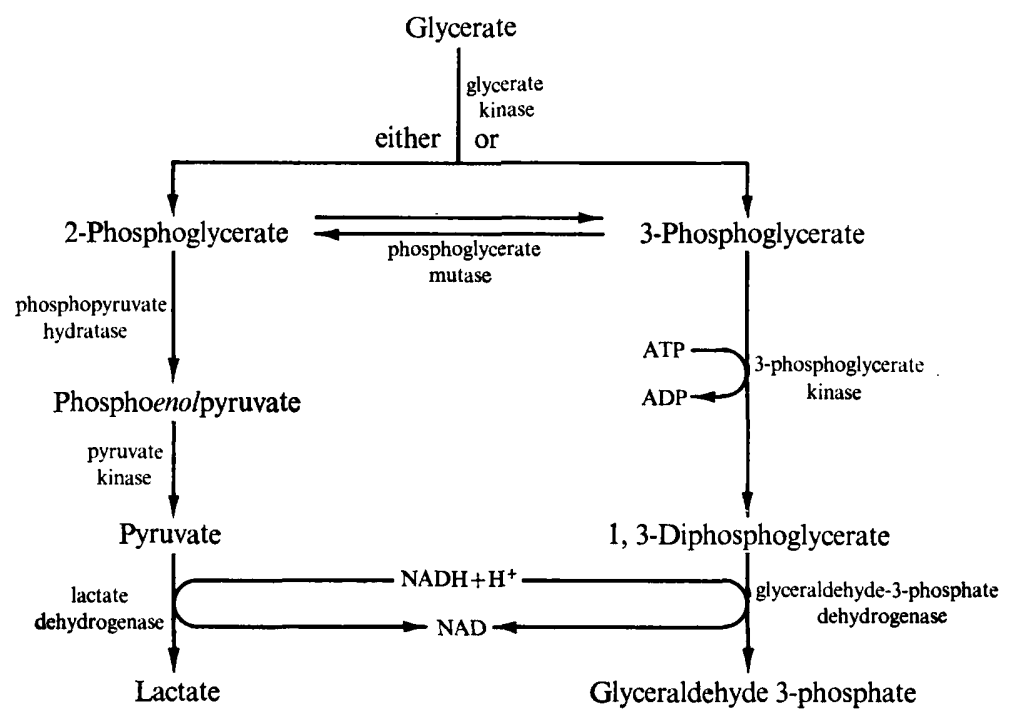

Fig. 1. Possible pathways for the metabolism of glycerate.

taining: $50 \mu \mathrm{mol}$ potassium phosphate buffer, $\mathrm{pH} 7 \cdot 0 ; 10 \mu \mathrm{mol}$ ATP; $10 \mu \mathrm{mol}$ DL-glyceric acid; $5 \mu \mathrm{mol}$ EDTA; and $10 \mu \mathrm{mol} \mathrm{MgCl}_{2}$. The identity of the resultant phosphorylated glycerate product was established by assaying samples of the incubation mixture in a reaction mixture (final vol. $1.0 \mathrm{ml}$ ) containing: $50 \mu \mathrm{mol}$ Tris buffer, $\mathrm{pH} 7 \cdot 3 ; 1 \mu \mathrm{mol}$ ADP; $0 \cdot 2 \mu \mathrm{mol} \mathrm{NADH}$; and $0.01 \mu \mathrm{mol} 2,3$-diphosphoglyceric acid. The absorbance at $340 \mathrm{~nm}$ was determined and then successively redetermined after the sequential addition of $50 \mu \mathrm{g}$ lactate dehydrogenase, then $20 \mu \mathrm{g}$ pyruvate kinase, then $20 \mu \mathrm{g}$ phosphopyruvate hydratase and then $1.0 \mathrm{ml}$ partially purified phosphoglycerate mutase ( $1 \mathrm{mg}$ protein).

Chemicals. DL-Glyceric acid, 2,3-diphosphoglyceric acid, 3-phosphoglyceric acid, 2-phosphoglyceric acid, lactate dehydrogenase (ex rabbit muscle), pyruvate kinase (ex rabbit muscle) and phosphopyruvate hydratase (ex rabbit muscle) were obtained from Boehringer.

\section{RESULTS AND DISCUSSION}

Comparison of the specific activities of glycerate kinase $\left[0.010 \mu \mathrm{mol} \mathrm{min}^{-1}(\mathrm{mg} \text { protein })^{-1}\right]$, phosphoglycerate mutase $\left[0.004 \mu \mathrm{mol} \mathrm{m^{-1 }}\right.$ (mg protein) $\left.{ }^{-1}\right]$ and phosphopyruvate hydratase $\left[0.021 \mu \mathrm{mol} \mathrm{min}{ }^{-1}(\mathrm{mg} \text { protein })^{-1}\right]$ in cell extracts of ethylene glycol-grown NCIB 11171 suggests that the conversion of glycerate into phosphoenolpyruvate $\left[0.009 \mu \mathrm{mol} \mathrm{min}{ }^{-1}\right.$

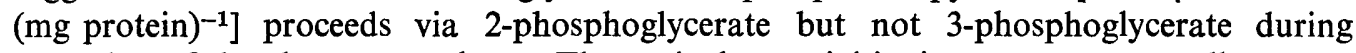
operation of the glycerate pathway. The equivalent activities in acetate-grown cell extracts of NCIB 11171 were $0,0.002,0.014$ and $0 \mu \mathrm{mol} \mathrm{min}{ }^{-1}(\mathrm{mg} \text { protein })^{-1}$, respectively.

Glycerate kinase, phosphoglycerate mutase and 3-phosphoglycerate kinase from ethylene glycol-grown NCIB 11171 appear to be separate single protein moieties as assessed by gel filtration on Bio-Gel P300 (Fig. 2), although the initial fractions of phosphoglycerate mutase activity were eluted together with the later fractions of glycerate kinase activity. The product of purified glycerate kinase (fraction no. 20, Fig. 2) was indirectly confirmed as 2-phosphoglycerate. The failure of the successive addition of lactate dehydrogenase and pyruvate kinase to promote any decrease in absorbance at $340 \mathrm{~nm}$ indicated that neither pyruvate nor phosphoenolpyruvate were initially present in the product identification reaction mixture. The presence of 2-phosphoglycerate was confirmed by the rapid decrease in absorbance at $340 \mathrm{~nm}$ observed after the subsequent addition of phosphopyruvate hydratase. The failure of the further addition of partially purified phosphoglycerate mutase (fraction no. 26, Fig. 2) to promote any change in the absorbance at $340 \mathrm{~nm}$ indicated that no 3-phosphoglycerate, the product of glycerate kinase in glycerol-grown E. coli (Doughty et al., 1966), was present 

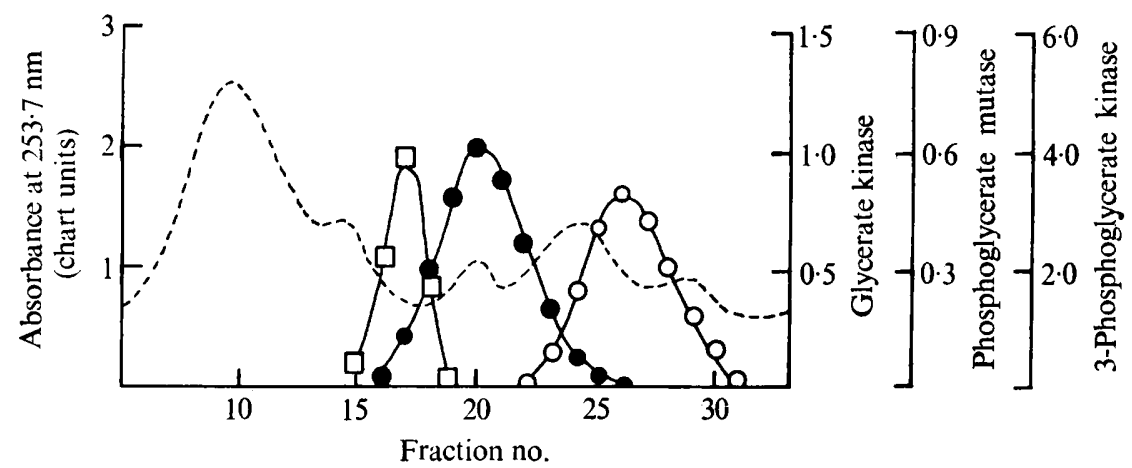

Fig. 2. Separation and partial purification of enzymes involved in ethylene glycol metabolism by Flavobacterium sp. NCIB 11171. An extract of ethylene glycol-grown cells, after fractionation with $\left(\mathrm{NH}_{4}\right)_{2} \mathrm{SO}_{4}$, was chromatographed on Bio-Gel P300 and fractions were assayed for glycerate kinase, phosphoglycerate mutase and 3-phosphoglycerate kinase activities as described in Methods. Protein was detected automatically by measuring absorption at $253.7 \mathrm{~nm}$ with an LKB Uvicord I UV absorptiometer. Enzyme activities were found only in the fractions shown. $\bigcirc$, Phosphoglycerate mutase activity; - , glycerate kinase activity; $\square$, 3-phosphoglycerate kinase activity; ----, absorbance at $253 \cdot 7 \mathrm{~nm}$. All enzyme activities are expressed as $\mu$ mol $\mathrm{min}^{-1}\left(\mathrm{mg}\right.$ protein) ${ }^{-1}$.

in the product identification reaction mixture. A decrease in absorbance at $340 \mathrm{~nm}$ consequent on the addition of $10 \mu \mathrm{mol} 3$-phosphoglycerate established the competence of the product identification reaction mixture to detect endogenous 3-phosphoglycerate and thereby implied that 2-phosphoglycerate was the reaction product of glycerate kinase in ethylene glycol-grown NCIB 11171 . The absence of any detectable phosphoglycerate mutase activity from the commercial preparations of lactate dehydrogenase, pyruvate kinase and phosphopyruvate hydratase used in the assays supported the suggestion that 2-phosphoglycerate was the reaction product of glycerate kinase in ethylene glycol-grown NCIB 11171. The absence of 3-phosphoglycerate kinase (fraction no. 15 to 19, Fig. 2) from the partially purified glycerate kinase and phosphoglycerate mutase preparations used in the assays decreased the possibility that the 3-phosphoglycerate kinase plus glyceraldehyde-3-phosphate dehydrogenase-dependent metabolism of 3-phosphoglycerate to glyceraldehyde 3phosphate via 1,3-diphosphoglycerate interfered with the observed activities as in crude cell-free extracts of Hyphomicrobium x (Hill \& Attwood, 1976b). The phosphoglycerate mutase present in ethylene glycol-grown NCIB 11171 may serve as the first enzyme in the pathway of gluconeogenesis operating during growth on the aliphatic glycol: an equivalent role for the enzyme has been suggested in methanol-grown Hyphomicrobium x (Harder et al., 1973).

\section{REFERENCES}

Child, J. \& Willetts, A. (1978). Microbial metabolism of aliphatic glycols. Bacterial metabolism of ethylene glycol. Biochimica et biophysica acta 538, 316-327.

Doughty, C. C., Hayashi, J. A. \& Guenther, H. L. (1966). Purification and properties of D-glycerate 3-kinase from Escherichia coli. Journal of Biological Chemistry 241, 568-572.

Harder, W., AtTwood, M. M. \& Quayle, J. R. (1973). Methanol assimilation by Hyphomicrobium sp. Journal of General Microbiology 78, 155-163.

Hill, B. \& AtTwood, M. M. (1974). The purification of glycerate kinase from Hyphomicrobium sp. and Pseudomonas AM1: product identification. Journal of General Microbiology 83, 187-190.
Hill, B. \& Atrwood, M. M. (1976a). Purification and characterization of phosphoglycerate mutase from methanol-grown Hyphomicrobium $\mathrm{x}$ and Pseudomonas AM1. Journal of General Microbiology 96, 185-193.

Hill, B. \& ATtwood, M. M. (1976b). The effect of adenosine triphosphate on phosphoglycerate mutase activity from Hyphomicrobium $\mathrm{x}$ and Pseudomonas AM1 grown on reduced one-carbon compounds. Journal of General Microbiology 97, 335-338.

Lowry, O. H., Rosebrough, N. J., Farr, A. L. \& Randall, R. J. (1951). Protein measurement with Folin phenol reagent. Journal of Biological Chemistry 193, 265-275.

Newaz, S. S. \& Hersh, L. B. (1975). Reduced nico- 
tinamide adenine dinucleotide-activated phosphoenolpyruvate carboxylase in Pseudomonas MA: potential regulation between carbon assimilation and energy production. Journal of Bacteriology 124, 825-833.

Roustan, C., Brevet, A., Pradel, L. A. \& Von
ThoAI, N. (1973). Yeast 3-phosphoglycerate kinase. Interaction of the enzyme with substrates studied by partial isotope exchange and difference spectrophotometry. European Journal of Biochemistry 37, 248-255. 